\title{
The Influence of Return on Equity Ratio and Debt to Equity Ratio to Price to Earning Ratio in Galvalum Companies Listed on the Indonesia Stock Exchange for the 2014-2018 Period
}

\author{
Hendro Waryanto \\ Universitas Pamulang \\ E-mail: hendrowaryanto@gmail.com
}

(Received: December-2018; Reviewed: January-2019; Accepted: February-2019;

Avalaibel Online: February-2019; Published: March-2019)

\begin{abstract}
The development of the capital market in Indonesia has encouraged companies to sell their shares to the public so that more companies are listed on the Indonesian stock exchange. This study aims to determine the effect of Return On Equity Ratio and Debt to Equity Ratio on Price to Earning Ratio in Galvalum Companies listed on the Indonesia Stock Exchange Period 2014-2018. The method used is explanatory research with a sample of 5 years of financial statements. The analysis technique uses statistical analysis with regression testing, correlation, determination, and hypothesis testing. The results of this study Return On Equity Ratio significantly influence the Price to Earning Ratio of 47.8\%, the hypothesis test obtained significance of $0,000<0.05$. Debt to Equity Ratio has no significant effect on Price to Earning Ratio of $0.01 \%$, the hypothesis test obtained significance of $0.900>0.05$. Return On Equity Ratio and Debt to Equity Ratio simultaneously have a significant effect on Price to Earning Ratio of 49.2\%, hypothesis testing obtained significance of $0,000<0.05$.
\end{abstract}

Keywords: Return on equity ratio, debt to equity ratio, price to earning ratio.

\section{INTRODUCTION}

The development of the capital market in Indonesia has encouraged companies to sell their shares to the public so that more companies are listed on the Indonesian stock exchange (Alwi, 2008; Hariyani \& Purnomo, 2010; Market \& Pendahuluan, 2015; Sujana, 2017). Every year a publicly listed company listed on the Indonesian stock exchange is obliged to submit its financial statements because financial statement information is an important element for investors and business people for the purposes of analysis and decision making (Almilia \& Kristijadi, 2003; Barus \& Christina, 2014; Christine et al., 2019; Saleh \& Sudiyatno, 2013).

Before an investor will invest in the capital market there is the most important activity that needs to be done, namely a careful evaluation of the traded equity. There is a belief that the 
information received by investors is correct information, trading systems on the stock exchange that can be trusted, and no other party who manipulate the information and trade. In terms of analyzing a company, investors can use financial statements to assess the condition of the company.

One of the tools for selecting and analyzing stocks to be bought by investors can use financial ratio analysis (Edy Susanto, 2019; Faisal, Samben, \& Pattisahusiwa, 2018; Harahap, 2007; Pramono, 2014; Pranomo, 2014). Financial ratio analysis is based on historical finance with the aim of giving an indication of future financial performance and predicting business continuity.

Analysis of financial statements is needed by analysts and investors to take investment policies (Hery, 2019; Kasmir, 2014; Munawir, 2010; Murhadi, 2015; Orniati, 2009). One of the analysis tools needed is fundamental analysis, which tries to estimate future stock prices by estimating the value of fundamental factors that affect stock prices in the future. In fundamental analysis, one stock valuation is carried out using the Price Earning Ratio (PER) approach, which is the ratio between the stock market price and earnings per share (Law Ren Sia \& Tjun Tjun, 2011; Prasetyorini, 2013; Putri, 2012). Every share price movement will cause changes in PER. And in this study the analysis of financial ratios used is PER (Price Earning Ratio), this analysis compares the current market price of shares with earnings per share. PER (Price Earning Ratio) is the most widely used financial ratio of investors to determine whether a stock investment is profitable or not, because PER (Price Earning Ratio), is one of the tools to measure the company's performance and can affect the increase or decrease in the company's stock market price. Investors are interested in PER (Price Earning Ratio), high because it will provide benefits for rising stock market prices and reflect good company performance (Aditya, 2014; Beidleman, 1971; Wahyu Lusiana, 2010).

There are many factors that affect the Price to Earning Ratio one of which is the profitability ratio in this study measured Return On Equity (ROE). Return on Equity (ROE) is a ratio that shows how much the company's ability to generate net income for return of equity to shareholders. Another factor is the capital structure is a picture of the form of the company's financial proportions, namely between owned capital sourced from long-term debt and own capital which is a source of financing for a company (Astuti, Retnowati, \& Rosyid, 2015; Supiyadi, Ramdhonah, \& Fithriani, 2016; Tambunan, 2015).

Capital structure research uses Debt Equity Ratio (DER). Debt Equity Ratio (DER) to measure a company's ability to meet obligations in paying its debts with a guarantee of its own capital. The trade-off theory predicts a positive relationship between capital structure and firm value assuming that tax profits are still greater than the costs of financial pressures and agency costs. The trade-off theory also predicts a positive relationship between capital structure and the level of profitability or financial performance of the company.

Analysis in the financial statements is a process that is full of consideration in helping to evaluate the financial position and results of the company's operations in the present and the past with the aim of predicting the changing conditions of performance in the future. Investors can observe financial performance by evaluating and projecting stock prices. If the profits obtained by the company are good, then the company's value will be even better. All companies in Indonesia experienced fluctuating company values in all sectors. No exception in the galvalume sub-sector.

\section{METHOD}

The type of research used is associative, where the aim is to find out the relationship between variables. The population in this study amounted to 5 years of Galvalum Company's 
financial statements listed on the Indonesia Stock Exchange for the 2014-2018 period. The sampling technique in this study is saturated sampling, where all members of the population are sampled. Thus the sample in this study amounted to 5 years of financial statements. In analyzing the data used the instrument test, classical assumption test, regression, coefficient of determination and hypothesis testing.

\section{RESULT AND DISCUSSION}

The Indonesia Stock Exchange or the capital market functions to connect investors, companies and government institutions through the trading of long-term financial instruments and one of the instruments traded is shares.

\section{Descriptive Analysis}

In this test is used to determine the highest minimum and maximum scores, average values and standard deviations of each variable. The results are as follows:

Table 1.

Descriptive Statistics Analysis Results

Descriptive Statistics

\begin{tabular}{|l|r|r|r|r|r|r}
\hline & $\mathrm{N}$ & \multicolumn{1}{|c|}{ Minimum } & Maximum & \multicolumn{1}{c|}{ Mean } & Std. Deviation \\
\hline Return on Equity & 20 & -2 & 1 & .03 & .586 \\
\hline Debt To Equity Ratio & 20 & -8 & 9 & .43 & 3.201 \\
\hline Price to Earning Ratio & 20 & -13 & 40 & 14.41 & 14.759 \\
\hline Valid N (listwise) & 20 & & & & \\
\hline
\end{tabular}

Return On Equity Ratio obtained a minimum variance of -2 and a maximum variance of 1 with an average value of $0.03 \%$ with a standard deviation of 0.586 . Debt to Equity Ratio obtained a minimum variance of -8 and a maximum variance of 9 with an average value of $0.43 \%$ with a standard deviation of 3.201. Price to Earning Ratio obtained a minimum variance of -13 and a maximum variance of 40 with an average value of $14.41 \%$ with a standard deviation of 14.759 .

\section{Multiple Regression Analysis}

This regression test is intended to determine changes in the dependent variable if the independent variable changes. The test results are as follows:

Table 2.

Multiple Regression Testing Results

\begin{tabular}{|c|c|c|c|c|c|}
\hline \multirow[b]{3}{*}{ Model } & \multicolumn{3}{|c|}{ Coefficients $^{\mathrm{a}}$} & \multirow[b]{3}{*}{$\mathrm{t}$} & \multirow[b]{3}{*}{ Sig. } \\
\hline & \multicolumn{2}{|c|}{$\begin{array}{l}\text { Unstandardized } \\
\text { Coefficients }\end{array}$} & \multirow{2}{*}{$\begin{array}{l}\text { Standardized } \\
\text { Coefficients } \\
\text { Beta }\end{array}$} & & \\
\hline & $\mathrm{B}$ & Std. Error & & & \\
\hline 1 (Constant) & 14.017 & 2.513 & & 5.578 & .000 \\
\hline Return on Equity & 18.034 & 4.452 & .717 & 4.051 & .001 \\
\hline Debt To Equity Ratio & -.557 & .816 & -.121 & -.683 & .504 \\
\hline
\end{tabular}

a. Dependent Variable: Price to Earning Ratio 
Volume 2, Issue 2, March, 2019 Page. 185- 192

Based on the test results in the above table, the regression equation $Y=14.017+18.034 \mathrm{X}$ $0.557 \mathrm{X} 2$ is obtained. A constant of 14,017 means that if there is no Return on Equity Ratio and Debt to Equity Ratio, then there is a Price to Earning Ratio of 14,017 points. The regression coefficient of Return On Equity Ratio of 18,034, this number is positive meaning that every time there is an increase in Return On Equity Ratio of 18,034 the Price to Earning Ratio will also increase by 18,034 points. Debt to Equity Ratio regression coefficient of -0.557 , this number is positive meaning that every time there is a change in Debt to Equity Ratio of -0.557 then the Price to Earning Ratio will also change by -0.557 points.

\section{Correlation Coefficient Analysis}

Correlation coefficient analysis is intended to determine the degree of relationship strength of the independent variables on the dependent variable either partially or simultaneously. The test results are as follows:

Table 3.

Test Results Correlation Coefficient Return On Equity Ratio Against Price to Earning Ratio. Correlations $^{\mathrm{b}}$

\begin{tabular}{ll|r|r}
\hline & & $\begin{array}{c}\text { Return on } \\
\text { Equity }\end{array}$ & $\begin{array}{c}\text { Price to Earning } \\
\text { Ratio }\end{array}$ \\
\hline Return on Equity & Pearson Correlation & 1 & $.691^{* *}$ \\
\cline { 2 - 4 } & Sig. (2-tailed) & & .001 \\
\hline Price to Earning Ratio & Pearson Correlation & $.691^{* *}$ & 1 \\
& Sig. (2-tailed) & .001 & \\
\hline
\end{tabular}

**. Correlation is significant at the 0.01 level (2-tailed).

b. Listwise $\mathrm{N}=20$

Based on the test results obtained by a correlation value of 0.691 means that the Return On Equity Ratio has a strong relationship to Price to Earning Ratio.

Table 4.

Test Results Correlation Coefficient Debt to Equity Ratio Against Price to Earning Ratio.

Correlations $^{\mathrm{a}}$

\begin{tabular}{llr|r}
\hline & & \multicolumn{1}{c}{$\begin{array}{c}\text { Debt To } \\
\text { Equity Ratio }\end{array}$} & \multicolumn{1}{c}{$\begin{array}{c}\text { Price to } \\
\text { Earning Ratio }\end{array}$} \\
\hline ebt To Equity Ratio & Pearson Correlation & 1 & .030 \\
\cline { 2 - 4 } & Sig. (2-tailed) & & .900 \\
\hline Price to Earning Ratio & Pearson Correlation & .030 & 1 \\
\cline { 2 - 4 } & Sig. (2-tailed) & .900 & \\
\hline
\end{tabular}

a. Listwise $\mathrm{N}=20$

ased on the test results obtained by a correlation value of 0.030 means that Debt to Equity Ratio has a very weak relationship to Price to Earning Ratio. 
Table 5

Test Results Correlation Coefficient Return On Equity Ratio and Debt to Equity Ratio Simultaneously Against Price to Earning Ratio.

Model Summary

\begin{tabular}{lrr|rr|r}
\hline Model & & R & \multicolumn{1}{c|}{$\begin{array}{c}\text { Adjusted R } \\
\text { Square }\end{array}$} & $\begin{array}{c}\text { Std. Error of the } \\
\text { Estimate }\end{array}$ \\
\hline 1 & $.701^{\mathrm{a}}$ & \multicolumn{1}{c|}{ R Square } & .492 & .432 & 11.125 \\
\hline
\end{tabular}

a. Predictors: (Constant), Debt To Equity Ratio, Return on Equity

Based on the test results obtained by a correlation value of 0.701 means that Return On Equity Ratio and Debt to Equity Ratio simultaneously have a strong relationship to Price to Earning Ratio.

\section{Analysis of the Coefficient of Determination}

Analysis of the coefficient of determination is intended to determine the percentage of influence of the independent variable on the dependent variable either partially or simultaneously. The test results are as follows:

Table 6.

Test Results for the Determination Coefficient of Return On Equity Ratio Against Price to Earning Ratio.

Model Summary

\begin{tabular}{l|r|rrr}
\hline \multicolumn{1}{c|}{$\mathrm{R}$} & \multicolumn{2}{c|}{$\begin{array}{c}\text { Adjusted R } \\
\text { Sqdel }\end{array}$} & $\begin{array}{c}\text { Std. Error of the } \\
\text { Estimate }\end{array}$ \\
\hline 1 & $.691^{\mathrm{a}}$ & .478 & .449 & 10.959 \\
\hline a. Predictors: (Constant), Return on Equity
\end{tabular}

Based on the test results obtained a determination value of 0.478 means that the Return On Equity Ratio has an influence contribution of $47.8 \%$ to the Price to Earning Ratio.

Table 7.

Test Results Determination Coefficient Debt to Equity Ratio Against Price to Earning Ratio. Model Summary

\begin{tabular}{|c|c|c|c|c|}
\hline Model & $\mathrm{R}$ & R Square & $\begin{array}{c}\text { Adjusted R } \\
\text { Square }\end{array}$ & $\begin{array}{c}\text { Std. Error of the } \\
\text { Estimate }\end{array}$ \\
\hline 1 & $.030^{\mathrm{a}}$ & .001 & -.055 & 15.157 \\
\hline
\end{tabular}

a. Predictors: (Constant), Debt to Equity Ratio

Based on the test results obtained a determination value of 0.001 means that Debt to Equity Ratio has an influence contribution of $0.01 \%$ to the Price to Earning Ratio. 
Table 8 .

Testing Results Determination Coefficient Return On Equity Ratio and Debt to Equity Ratio Against Price to Earning Ratio.

\begin{tabular}{|c|c|c|c|c|}
\hline \multicolumn{5}{|c|}{ Model Summary } \\
\hline Model & $\mathrm{R}$ & R Square & $\begin{array}{l}\text { Adjusted R } \\
\text { Square }\end{array}$ & $\begin{array}{l}\text { Std. Error of the } \\
\text { Estimate }\end{array}$ \\
\hline 1 & $.701^{\mathrm{a}}$ & .492 & .432 & 11.125 \\
\hline
\end{tabular}

a. Predictors: (Constant), Debt To Equity Ratio, Return on Equity

Based on the test results obtained a determination value of 0.492 means that Return On Equity Ratio and Debt to Equity Ratio simultaneously have an influence contribution of $49.2 \%$ to Price to Earning Ratio, while the remaining $50.8 \%$ is influenced by other factors.

\section{Hypotesis Testing}

Hypothesis testing with t-test is used to find out which partial hypotheses are accepted.

Table 9.

Hypothesis Test Results Return On Equity Ratio Against Price to Earning Ratio.

Coefficients $^{\mathbf{a}}$

\begin{tabular}{|c|c|c|c|c|c|}
\hline \multirow[b]{2}{*}{ Model } & \multicolumn{2}{|c|}{$\begin{array}{c}\text { Unstandardized } \\
\text { Coefficients }\end{array}$} & \multirow{2}{*}{$\begin{array}{c}\text { Standardized } \\
\text { Coefficients } \\
\text { Beta }\end{array}$} & \multirow[b]{2}{*}{ 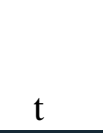 } & \multirow[b]{2}{*}{ Sig. } \\
\hline & B & Std. Error & & & \\
\hline 1 (Constant) & 13.799 & 2.455 & & 5.620 & .000 \\
\hline Return on Equity & 17.394 & 4.287 & .691 & 4.057 & .001 \\
\hline
\end{tabular}

a. Dependent Variable: Price to Earning Ratio

Based on the test results in the table above, the value of $t_{\text {count }}>t_{\text {table }}$ or $(4.057>2.101)$ is obtained, thus the first hypothesis proposed that there is a significant influence between Return On Equity Ratio to Price to Earning Ratio is accepted.

Table 10.

Debt to Equity Ratio Hypothesis Test Results Against Price to Earning Ratio.

Coefficients $^{\mathbf{a}}$

\begin{tabular}{|c|c|c|c|c|c|}
\hline \multirow[b]{2}{*}{ Model } & \multicolumn{2}{|c|}{$\begin{array}{l}\text { Unstandardized } \\
\text { Coefficients }\end{array}$} & \multirow{2}{*}{$\begin{array}{c}\text { Standardized } \\
\text { Coefficients } \\
\text { Beta } \\
\end{array}$} & \multirow[b]{2}{*}{$\mathrm{t}$} & \multirow[b]{2}{*}{ Sig. } \\
\hline & $\mathrm{B}$ & Std. Error & & & \\
\hline (Constant) & 14.348 & 3.422 & & 4.193 & .001 \\
\hline Debt To Equity Ratio & .138 & 1.086 & .030 & .127 & .900 \\
\hline
\end{tabular}

a. Dependent Variable: Price to Earning Ratio

Based on the test results in the above table, the value of $t_{\text {count }}<t_{\text {table }}$ or $(0.127<2.101)$ is obtained, thus the second hypothesis proposed that there is no significant effect between Debt to Equity Ratio to Price to Earning Ratio is accepted.

Hypothesis testing with the F test is used to find out which simultaneous hypotheses are accepted. 
Table 11.

Hypothesis Test Results Return on Equity Ratio and Debt to Equity Ratio Against Price to Earning Ratio.

\begin{tabular}{|c|c|c|c|c|c|c|}
\hline \multicolumn{7}{|c|}{ ANOVA $^{\mathbf{a}}$} \\
\hline & & Sum of Squares & df & Mean Square & $\mathrm{F}$ & Sig. \\
\hline \multirow[t]{3}{*}{1} & Regression & 2034.855 & 2 & 1017.428 & 8.220 & $.003^{\mathrm{b}}$ \\
\hline & Residual & 2104.104 & 17 & 123.771 & & \\
\hline & Total & 4138.960 & 19 & & & \\
\hline
\end{tabular}

a. Dependent Variable: Price to Earning Ratio

b. Predictors: (Constant), Debt To Equity Ratio, Return on Equity

Based on the test results in the above table, the calculated $F$ count $>F_{\text {table }}$ or $(8.220>3.200)$, thus the third hypothesis proposed that there is a significant influence between the Return On Equity Ratio and Debt to Equity Ratio to Price to Earning Ratio accepted.

\section{CONCLUSION}

Based on the results of the study, the Return On Equity Ratio significantly influence the Price to Earning Ratio with a contribution of $47.8 \%$. Hypothesis testing obtained $t_{\text {count }}>t_{\text {table }}$ or (4.057> 2.101). Debt to Equity Ratio has no significant effect on Price to Earning Ratio with an influence contribution of $0.01 \%$. Hypothesis testing obtained $t_{\text {count }}<t_{\text {table }}$ or $(0.127<2.101)$. Return On Equity Ratio and Debt to Equity Ratio has a significant effect on Price to Earning Ratio with a contribution of $49.2 \%$ while the remaining $50.8 \%$ is influenced by other factors. Hypothesis testing obtained by the calculated $\mathrm{F}_{\text {count }}>\mathrm{F}_{\text {table }}$ or $(8.220>3.200)$.

\section{REFERENCES}

Aditya, R. Y. (2014). Pengaruh Kinerja Keuangan Terhadap Harga Saham Pada Perusahaan Rokok Di Bursa Efek Indonesia. Jurnal Ilmu dan Riset Manajemen.

Almilia, L. S., \& Kristijadi, E. (2003). Analisis Rasio Keuangan Untuk Memprediksi Kondisi Financial Distress Perusahaan Manufaktur Yang Terdaftar di Bursa Efek Jakarta. Jurnal Akuntansi \& Auditing Indonesia.

Alwi, I. Z. (2008). Pasar Modal Teori dan Aplikasi. In Yayasan Pancur Siwah.

Astuti, K. D., Retnowati, W., \& Rosyid, A. (2015). Pengaruh Struktur Modal Terhadap Profitabilitas ( Studi Pada Perusahaan Go Publik Yang Menjadi 100 Perusahaan Terbaik Versi Majalah Fortune Indonesia Periode Tahun 2010-2012 ). Jurnal Akuntansi.

Barus, A. C., \& Christina. (2014). Pengaruh Reaksi Pasar Terhadap Harga Saham Perusahaan yang Terdaftar di Bursa Efek Indonesia. Jurnal Wira Ekonomi Mikroskil.

Beidleman, C. R. (1971). Limitations of Price-Earnings Ratio. Financial Analysts Journal. https://doi.org/10.2469/faj.v27.n5.86

Christine, D., Wijaya, J., Chandra, K., Pratiwi, M., Lubis, M. S., \& Nasution, I. A. (2019). Pengaruh Profitabilitas, Leverage, Total Arus Kas dan Ukuran Perusahaan terhadap Financial Distress pada Perusahaan Property dan Real Estate yang Terdapat di Bursa Efek Indonesia Tahun 2014-2017. Jesya (Jurnal Ekonomi \& Ekonomi Syariah). https://doi.org/10.36778/jesya.v2i2.102 
Edy Susanto, M. (2019). Analisis Rasio Keuangan. Journal of Chemical Information and Modeling. https://doi.org/10.1017/CBO9781107415324.004

Faisal, A., Samben, R., \& Pattisahusiwa, S. (2018). Analisis kinerja keuangan. KINERJA. https://doi.org/10.29264/jkin.v14i1.2444

Harahap, S. S. (2007). Analisis Krirtis Atas Laporan Keuangan. Jakarta: PT.Raja Grasindo Persada.

Hariyani, I., \& Purnomo, S. D. (2010). Buku Pintar Hukum Bisnis Pasar Modal. Jakarta: Transmedia Pustaka.

Hery. (2019). Akuntansi Dasar 1 dan 2. Fundamental Management Journal.

Kasmir. (2014). Laporan Keuangan Bank. Manajemen Perbankan.

Law Ren Sia, V., \& Tjun Tjun, L. (2011). Pengaruh Current Ratio, Earnings Per Share, dan Price Earnings Ratio Terhadap Harga Saham. Akuntansi.

Market, P., \& Pendahuluan, A. (2015). Pasar Modal Dalam Perspektif Islam. Mazahib. https://doi.org/10.21093/mj.v14i1.332

Munawir. (2010). Analisa Laporan Keuangan Edisi 4. In Jakarta: Salemba Empat.

Murhadi, W. R. (2015). Analisis Laporan Keuangan Proyeksi dan Valuasi Saham. In Salemba Empat.

Orniati, Y. (2009). Laporan Keuangan sebagai Alat untuk Menilai Kinerja Keuangan. Jurnal ekonomi bisnis.

Pramono, J. (2014). Analisis Rasio Keuangan Untuk Menilai Kinerja Keuangan Pemerintah Daerah. Jurnal Ilmiah Among Makarti.

Pranomo, J. (2014). Analisis Rasio Keuangan Untuk Menilai Kinerja Keuangan Pemerintah Daerah (Studi Kasus Pada Pemerintah Kota Surakarta).(Joko Pramono). Jurnal Ilmiah Among Makarti.

Prasetyorini, B. F. (2013). Pengaruh Ukuran Perusahaan, Leverage, Price Earning Ratio dan Profitabilitas terhadap Nilai Perusahaan. Jurnal Ilmu Manajemen (JIM).

Putri, A. A. B. (2012). Analisis pengaruh ROA, EPS, NPM, DER dan PBV terhadap return saham. Diponegoro Business Review.

Saleh, A., \& Sudiyatno, B. (2013). Pengaruh Rasio Keuangan untuk Memprediksi Probabilitas Kebangkrutan pada Perusahaan Yang Terdaftar Di Bursa Efek Indonesia. Dinamika Akuntansi, Keuangan dan Perbankan. https://doi.org/1979-4878

Sujana, I. N. (2017). Pasar Modal yang Efisien. Ekuitas: Jurnal Pendidikan Ekonomi. https://doi.org/10.23887/ekuitas.v5i2.12753

Supiyadi, D., Ramdhonah, Z., \& Fithriani, M. (2016). Pengaruh Struktur Modal Terhadap Profitabilitas. Manajemen.

Tambunan, B. H. (2015). Pengaruh Struktur Modal terhadap Nilai Perusahaan. Jurnal Ilmiah “DUNIA ILMU.” https://doi.org/10.1016/j.ajem.2003.12.010

Wahyu Lusiana, F. (2010). Analisis Pengaruh Rasio Likuiditas, Rasio Solvabilitas, Rasio Aktivitas, Dan Rasio Profitabilitas Terhadap Price Earning Ratio Pada Perusahaan Manufaktur Yang Terdaftar Di Bursa Efek Indonesia. Jurnal Manajemen. 